\title{
An analysis of China's consular protection practice in Africa ${ }^{1}$
}

\author{
By Xia Liping*
}

China Foreign Affairs University

\begin{abstract}
Security issues involving overseas Chinese in Africa have been increasing recently, attracting extensive attention. Based on statistics gathered from the official website of the Chinese Foreign Ministry, and a questionnaire survey put to Chinese enterprises operating in Africa, the author summarizes various security risks which Chinese confront in Africa. The nature of the risks vary, including political risk, social security risk, risks caused by unlawful acts of Chinese citizens themselves, pandemic diseases, terrorist attacks, piracy, traffic accidents, financial fraud and natural disasters. The work explores how Chinese embassies and consulates in Africa, with the cooperation of Chinese companies, have established a diversified prevention mechanism and an efficient crisis response system in order to provide better protection to Chinese enterprises and citizens in Africa. The paper also addresses some of the pressing issues which still need to be addressed with regards to China's consular protection practice in Africa.
\end{abstract}

Xia Liping works at the China Foreign Affairs University (CFAU) in Beijing. CFAU is affiliated with the Ministry of Foreign Affairs of China. 


\section{AFRICAN \\ EAST-ASIAN AFFAIRS

\section{Introduction}

In terms of China's "going out" strategy, Africa serves as one of China's fastest growing destinations for project contracting and foreign direct investment. Currently, Africa serves as China's second largest engineering contracting market and fourth largest overseas investment destination. As of June 2012, more than 2,000 Chinese enterprises of various kinds in Africa were engaged within 50 African countries (People's Daily 2012 a). According to China's Ministry of Foreign Affairs most recent data, over 500000 Chinese have immigrated to Africa since the turn of the century (Ministry of Foreign Affairs, 2011 a). Media reports dating back to early 2012 state that around 1 million Chinese citizens have engaged in various business activities in Africa (Sina 2012). In recent years, the issue of protection has become a prominent issue, with African countries such as Egypt, Sudan, Congo (DRC), Nigeria and Ghana, amongst others, witnessing security incidents involving Chinese citizens. From July to September 2012, the author conducted a questionnaire in 18 African countries ${ }^{2}$ which surveyed 128 Chinese-funded enterprises ${ }^{3}$. Through a textual analysis of the questionnaire, this paper outlines the general characteristics of security threats both encountered and posed by Chinese citizens in Africa. The research also makes some suggestions as to how to improve the security of Chinese citizens abroad.

Consular protection policies are obliged to provide assistance to their nationals, such as providing international travel safety information, assistance to hire lawyers and translators, visiting detainees and helping evacuate dangerous areas (Qichen, 2005). Protection services extending beyond consular protection is an important aspect of this work, particularly to Chinese enterprises, where many Chinese citizens based in foreign countries work (Department of Consular Affairs 2010).

\section{The Security risk categories of Chinese citizens in Africa}

One of the primary sources of data for this project has been the Chinese Ministry of Foreign Affairs issuance of security alert messages. From 27 June, 2006, to 30 Octo- 
ber, 2012, the Ministry listed 932 security warnings; among them, 288 were related to African countries, accounting for $30.9 \%$ of the total, indicating that Chinese face significant risks within Africa.

Table 1: Security warnings issued by the MFA

(from June 2006 to October 2012)

\begin{tabular}{|l|l|l|l|}
\hline Regions & Security Warnings & Regions & Security Warnings \\
\hline Africa & 288 & North America & 30 \\
\hline Asia & 302 & $\begin{array}{l}\text { Latin America } \\
\text { and Caribbean }\end{array}$ & 49 \\
\hline Europe & 192 & Oceania & 69 \\
\hline Other & 2 & & \\
\hline Total & 932 & \multicolumn{2}{|l|}{} \\
\hline
\end{tabular}

Data Source: Website of the Ministry of Foreign Affairs (3)

The second, equally important source of information is the afore-mentioned survey. Questionnaires were sent to 128 Chinese companies of which only five of the countries ${ }^{4}$ are considered "safe" countries; approximately $60 \%$ of the companies (77) claimed that the countries in which they worked were safe and that daily life posed no problems; approximately $30 \%$ (39) of the companies claimed that they needed to exercise caution when going out; 5\% (7) of the respondents from the enterprises interviewed claimed that the countries in which they worked were very unsafe, and they needed to exercise caution at all times. These findings our outlined in Table 2.

Overall, the risks facing Chinese companies in Africa can be broadly divided into the nine following categories:

Political risk 


\begin{tabular}{|c|} 
AFRICAN \\
EAST-ASIAN \\
AFFAIRS \\
\hline THE CHINA MONITOR \\
\hline
\end{tabular}

Table 2: Types of security risks facing Chinese enterprises and Chinese citizens in Africa (5)

\begin{tabular}{|c|c|c|}
\hline & Chinese Enterprises & Chinese Citizens \\
\hline $\begin{array}{l}\text { Types of } \\
\text { Security } \\
\text { Risks }\end{array}$ & $\begin{array}{l}\text { political risks }(81 \%) \text {; } \\
\text { unfamiliar with local laws and } \\
\text { regulations }(61 \%) \text {; } \\
\text { bad public security, poor social order } \\
(56 \%) \text {; } \\
\text { difficulty in getting visa } \\
(26.5 \%) \text {; } \\
\text { difficulty in communicating with the } \\
\text { local residents and in integrating into } \\
\text { local community }(20 \%) \text {; } \\
\text { difficulty in dealing with local tribes } \\
\text { and factions ( } 10 \%) \text {; } \\
\text { others ( } 15.6 \%)\end{array}$ & $\begin{array}{l}\text { Poor social order }(61 \%) \text {; } \\
\text { unfamiliar with local laws and } \\
\text { regulations }(60 \%) \text {; } \\
\text { political risks }(43 \%) \text {; } \\
\text { unfriendliness of local people } \\
(15 \%) \text {; } \\
\text { others }(12.5 \%)\end{array}$ \\
\hline
\end{tabular}

Note: Other risks facing Chinese enterprises include no guarantees in the supply of raw materials; powerful trade unions; dishonesty of African business partners; epidemic diseases; traffic incidents and the risk of dual taxation. Other risks facing Chinese citizens in Africa include blackmailing by local people; traffic accidents; poor medical safety; misunderstandings caused by language barriers and different customs. Source: Based statistical results of survey questionnaire from July September, 2012. 
Political risk refers to social unrest caused by drastic changes in a political situation, such as general elections or the death or resignation of important leaders. Political risk is one of the biggest challenges facing Chinese enterprises in Africa. During the period from 27 June, 2006 to 30 October, 2012, the MFA issued 83 security warnings to do with political risk in African countries, constituting $28.8 \%$ of the total. Among the 128 Chinese enterprises who submitted the questionnaire, more than a third thought political risk was the most serious risk they faced in Africa. Over the past six years, the Department of State website posted about unrest safety tips related to Egypt, Burkina Faso, Burundi, Congo (DRC), Djibouti, Guinea, Guinea-Bissau, Gabon, Cameroon, Comoros, Côte d'Ivoire, Kenya, Lesotho, Libya, Madagascar, Mali, Mozambique, South Africa, Niger, Nigeria, Senegal, Sudan, South Sudan, Tunisia, Uganda, Zambia and Chad. Security warnings related to political risk in Africa covered 27 countries, nearly half of all African countries.

Unrest in African countries can be broadly attributed to some of the following factors: firstly, democratic governments whose democratic institutions are fragile are prone to unrest prior to, and following, election results. Such fragility entails that certain events, such as the death of a leader, can quickly lead to unrest. With the rapid growth of globalization, a given country's unrest can quickly spill-over into other countries. This has been evident with the "Arab Spring" phenomenon. In the first half of 2011, Tunisia, Egypt, Libya and other North African countries which were deemed relatively stable, faced rapid transformation. Other countries, traditionally regarded as stable, such as Mali and Burkina Faso, faced military mutinies (Beijing Youth Daily, 2012). Since January 1991, with the overthrow of the Siad regime in Somalia, the subsequent civil war has led to a situation where a number of regimes have co-existed at once. Additionally, Nigeria, Chad and Sudan have been negatively affected by the impact of anti-government forces. Another powerful force in the African political landscape is trade unions, who can orchestrate paralyzing strikes. This can be seen, for instance, in Nigeria in early 2012 when the federal government of Nigeria announced the cancellation of sub- 


\section{AFRICAN \\ EAST-ASIAN \\ AFFAIRS \\ THE CHINA MONITOR}

sides on refined oil products. Nigeria's unions organized a massive strike in the cities of Abuja and Lagos, causing confrontation between protesters and the police. The strikes brought traffic to a standstill, with armed bandits blocking highways and robbing passers-by.

Such events have had a serious impact on the safety of local Chinese citizens. For instance, after the military coup in Mali, a local, Chinese-run bar was looted. Two military vehicles carrying seven or eight soldiers approached the Chinese embassy and engaged in a stand-off with embassy guards; the soldiers fired shots and the guards were escorted away. The disintegration of the armed forces exacerbated the instability of the situation. Border clashes have also had implications for Chinese citizens. For instance, in April 2012, the border area between Sudan and South Sudan in the oil-rich Heglig region was subjected to clashes, leading to the evacuation of Chinese companies and citizens.

\section{Risks caused by poor social order}

Risks caused by poor social order can be attributed to robbery, theft, kidnapping and other criminal activities. Such activities are an important factor in securing the safety of Chinese citizens abroad. Security warnings issued by MFA related to this kind of risk cover 19 African countries (out of a total of 50 countries), making up for $35 \%$ of the total. Survey results show that $56 \%$ of Chinese enterprises and $61 \%$ Chinese citizens in Africa think that poor social order in host countries makes them feel insecure. Violent robbery and kidnapping are some of the gravest threats. In South Africa, Nigeria, Angola, Congo and other countries, during holidays or major events, robbery and theft are more serious. It is worth noting that, due to the impact of political unrest in North Africa, certain countries which enjoyed comparatively secure environments, began to undergo substantial change. For example, both Egypt and Tunisia were increasingly subject to domestic crimes such as armed robbery and theft. In March 2012, in the Egyptian capital of Cairo, two Chinese workers were kidnapped. According to an Egyptian security official, this was the first kidnapping of foreigners for ransom within Cairo that they could recall (Beijing Youth Daily 2012). 


\section{Security risks posed by the illegal acts of Chinese citizens}

Statistics from the Consular Section of the MFA indicate that nearly haft of the security problems involving overseas Chinese citizens are caused by their own improper acts (Weiwei 2008). Security warnings on the MFA's website also reflect this point. Improper acts of Chinese citizens in African countries include: (1) violation of local provisions of employment; (2) smuggling of ivory, pornography and cash reserves exceeding legal limits, as well as other contraband; (3) the use of forged visas; (4) the taking pictures in sensitive places; (5) smoking on airplanes; (6) bribing local police; (7) the illegal possession of alcohol and (8) failure to comply with other local laws and regulations. For example on May 22, 2012, 105 Chinese businessmen in Nigeria were detained under a drive to implement more stringent immigration policies. On the same day, 38 Chinese citizens suspected of illegal gold mining in Ghana were arrested. In October, a number of law enforcement agencies in Ghana's gold mining areas arrested more than 90 suspected illegal gold miners of Chinese origin, leading to the death of one Chinese citizen. The main problem arising from Chinese engagement with host countries' laws is twofold: firstly, there are certain Chinese nationals who do not properly understand the laws and regulations of the host country and secondly, there Chinese nationals who deliberately defy the law for their own selfish ends.

\section{The spread of epidemic diseases}

The African continent is prone to epidemic diseases which pose a substantial threat to foreign nationals. Security warnings issued by the MFA related to epidemic diseases in Africa involve 20 countries, about $37 \%$ of the total of African countries. Epidemic diseases have arisen in several countries including CongoBrazzaville, Ghana, Uganda, Tanzania and Mozambique. Types of disease including Ebola, Chikungya fever, cholera, Influenza A (sub-type H1N1), polio, dengue fever, anthrax, Rift Valley fever, H5N1, yellow fever and 10 other kinds of illnesses. Among them, cholera outbreaks are the most extensive. According to the Foreign Ministry website, from June 2006 to October 2012, Angola, Congo 


\section{AFRICAN \\ EAST-ASIAN \\ AFFAIRS \\ THE CHINA MONITOR}

(Brazzaville), Congo (DRC), Guinea-Bissau, Ghana, Zimbabwe, Malawi, Mozambique, Nigeria, Sierra Leone, Tanzania and the African Republic have all undergone large-scale epidemics.

\section{Terrorist attacks}

The Ministry of Foreign Affairs has published 33 security alerts on its web-site with regards to terrorist attacks. The countries involved include Nigeria, Niger, Kenya, Mali, Rwanda, Senegal, Mauritania, Algeria, Morocco, Egypt, Tanzania and another 11 countries. Chinese enterprises and citizens directly affected by terrorist activities can be divided into two cases, one in which Chinese citizens are directly targeted and the other where they are unfortunate, collateral victims of broader attacks which do not specifically target Chinese persons or enterprises. With regards to the former, in January 2007, five Chinese engineers in Nigeria's Rivers State were abducted by unidentified armed men; this was the first kidnapping of Chinese workers. In April, a Chinese oil company project team were attacked in Ethiopia by Somali militants; nine Chinese people were killed and seven were kidnapped. In July, employees of a Chinese company in Niger were kidnapped by members of the "Niger Movement for Justice". In January 2012,employees of Sino-Hydro Corporation, busy conducting a highway project in South Sudan's South Kordofan region, were attacked by the Sudan Peoples' Liberation Movement -North (SPLM-N). 29 Chinese workers were abducted, and one employee was killed. There are also instances of Chinese nationals being killed in attacks not specifically aimed at Chinese. For instance, in June 2010 in the Algerian province of Bouira, a suicide car-bomb attack killed a Chinese person working as a driver.

\section{Pirate attacks}

The Chinese Foreign Ministry website has issued 15 security warnings, mainly off the Somali coast. Since 1991, Somalia has been in a state of more-or-less constant conflict. The International Maritime Bureau had deemed the coastal region as the world's most dangerous waters. In the second half of 2008, foreign crews and ships 
were frequently attacked or hijacked by pirates near Somali waters. The Chinese government banned their crews and vessels entering waters near Somalia. In April 2009 various countries' warships patrolling the Gulf of Aden forced Somali piracy activities gradually eastward and southward, expanding 600 miles east of Somali waters and up to the region north of the Seychelles. Hijacking operations increased with multi-country, multi-vessel attacks. Maritime attacks increased elsewhere, such as $170 \mathrm{~km}$ off the Nigerian coast in February 2012, where eight armed pirates boarded a Chinese vessel in which both the captain and chief engineer were shot dead.

\section{Accidents}

The main risks attributed to accidents are traffic accidents and arsenal explosions. With regards to the former, Chinese were involved in three serious traffic accidents in Nigeria in the month of February 2010 alone. Although comparatively rare, there have also been two instances of arsenal bombings. On the evening of February $16^{\text {th }} 2011$, an explosion at a military base near Tanzania's Dare es Salaam International Airport caused damage to areas around the airport, leading to the closure of roads and the cancellation of flights. In March 4, 2012, an arsenal explosion in Congo Brazzaville, in the vicinity of Beijing Construction Engineering Group's social housing construction project, led to the death of six Chinese employees and caused injuries to another 45 .

\section{Economic fraud}

Security warnings of this nature have been related to Nigeria, Liberia, DRC, Benin and four other countries. In 2009, there were several cases of economic fraud reported in Liberia and Benin. In December 2010, 32 Chinese hospital workers gained employment at a Chinese company in the Congo, via an internet recruitment service. The employees contacted the Congolese embassy complaining that their freedom was restricted insofar as they were overworked and sometimes beaten and imprisoned. Additionally, their wages were reduced. The embassy assisted 


\section{AFRICAN \\ EAST-ASIAN \\ AFFAIRS \\ THE CHINA MONITOR}

in their return home. In November and December 2011, a number of Chinese business people in Nigeria contacted the Chinese Consulate General in Lagos complaining that they had been defrauded while trying to send remittances home. The Consulate General issued two consecutive warnings regarding fraud in Nigeria.

\section{Natural disasters}

Tanzania and Nigeria have been subject to severe floods, leading to a serious impact on the lives of local residents as well as Chinese institutions and their personnel. For example, in December 2011, Dar es Salaam and other regions of Tanzania experienced heavy rains triggered by floods; this resulted in 20 deaths and left nearly 5,000 people homeless. Traffic in Dar es Salaam came to a standstill with roads, railways and bridges seriously damaged. In April 2012, the Chinese Ambassador to Tanzania issued safety tips during the rainy season, reminding Chinese-funded enterprises and Chinese citizens of possible flooding and how a lack of attention to disaster and disease prevention measures could exacerbate the situation. Chinese citizens whose homes, workplaces and factories were located in low-lying areas need to make contingency plans. In October, the Chinese Consulate General in Lagos issued a safety alert on the embassy website to inform Chinese institutions and citizens that six states were threatened by floods caused by torrential rain, reminding them to take effective measures, such as flood control work, to ensure the safety of persons and property .

The above security risks that Chinese face in Africa are complex and diverse. Certainly, some of these risks are ones which Chinese have suffered in various other parts of the globe including illegal activities by Chinese citizens themselves, accidents and natural disasters. However, certain security risks are more prominent in Africa, such as political risk, security issues, epidemics, piracy and so on.

\section{Features of African consular protection}

As mentioned above, both Chinese-funded enterprises and Chinese citizens within Africa face a number of heterogeneous risks. To addresses these security issues, Chi- 
nese consular protection services need to adjust accordingly to the varied situations of the region.

In addressing the volatile political and security situation in Africa, the Chinese Foreign Ministry within African consulates, other government departments and Chinese-funded enterprises need to pay attention to the variety of ways in which preventive consular protection can be administered.

Firstly, in terms of African elections which are susceptible to causing instability, the Chinese Embassy and consulates need to remind local and overseas-funded enterprises to be vigilant and employ safety precautions. In April 2010, with the Sudanese national elections approaching, the Consulate General in Juba took measures to remind local and overseas-funded enterprises to improve security awareness, with timely exchange of relevant information between both the consulate and business and sustained close contact between the two parties. Prior to the Mali coup of 2012, the Chinese embassy repeatedly reminded the relevant enterprises to take precautionary measures in advance. During the coup, the embassy has held three meetings which included political and security updates. There was a drive to reduce the number of unnecessary personnel in the county as well as deploying all possible measures to protect the personal safety of construction workers.

Secondly, changes in a given country's political situation need to be monitored as they have implications for the Chinese-funded enterprises, property and the personal safety of citizens; such safety depends on maintaining contact with new regimes. After the shift in power of the Libyan government on September 12, 2012, the Chinese government announced its recognition of the Libyan "National Transitional Council" as the ruling authority of Libya and expressed the wish that earlier agreements and treaties between the Libyans and the Chinese would continue to be valid (Xinhua, 2011). After the coup in Mali, the Chinese embassy successfully obtained assurances from the military and transitional government leaders that Chinese enterprises and personnel would not be harmed (Ministry of Foreign Af- 


\section{AFRICAN \\ EAST-ASIAN \\ AFFAIRS \\ THE CHINA MONITOR}

fairs, 2012 a).

Thirdly, Chinese embassies, consulates and enterprises in African countries think highly of cultivating good relations with local influential groups. In March 2011, Chinese embassy diplomats stationed in Ethiopia drove to over 3200 meters above sea level to the village of Dodola in order to consult with administrative official and tribal elders (Ministry of Foreign Affairs, 2011 b). China Civil Engineering Construction Corporation, which has been operating in Nigeria for many years, has set rules that its managers must pay a visit to influential people and local youth organizations at each new place where they intend to start a business (CCTV 2007). Additionally, during the Libya evacuation in March, 2011, Chinese State Owned Enterprise played a very important role in accomplishing the evacuation. China Communication Construction Company Ltd took the initiative to contact local powerful figures to open the route for evacuation when the chartered liners could not pull into shore.

Fourth, considering the poor social order in African countries, Chinese embassies and consulates need to keep close links with local police, the interior ministry and other law enforcement agencies. Joint mechanisms on safeguarding the security of local Chinese composed by Chinese and local police have been established in some African countries such as South Africa, Mozambique and Lesotho. As early as March 2004, the Chinese Embassy in South Africa fostered strong ties with Chinese at the South Africa Police Cooperation Centre. The centre is a non-profit organization run jointly by Chinese communities and the police. The centre is responsible for answering calls from Chinese in order to help them deal with language barriers, unfamiliar legal processes and other issues. The Police Cooperation Centre also works with local police agencies to establish business contacts, familiarize themselves with the work of police procedures and to build interactive channels to allow the police to learn more about the difficulties faced by overseas Chinese communities. In 2011, the Chinese Embassy in Mozambique and the Mozambican police established the "Sino-Mozambican police and defence mechanism" (Ministry of Foreign Affairs, 
2012 b). The Chinese Embassy in Lesotho works with the Lesotho Ministry of Foreign Affairs, Ministry of Interior and other relevant departments to establish joint security mechanisms (Ministry of Foreign Affairs, 2012 c). The Chinese Ambassador to Tanzania, responsible for the safety of the commercial councillor, regularly consults with the Ministry of the Interior and has encouraged the police to promptly resolve cases involving the protection of Chinese citizens. Such cooperation contributes toward diffusing individual events which may, through accumulation, lead to larger security problems ${ }^{5}$. With the approval of the Angolan government (Ministry of Foreign Affairs, 2011 c), China's Ministry of Public Security sent a working team to Angola in May 2012 to investigate crimes involving Chinese citizens there. Crimes included robbery, kidnapping, extortion, abduction of women, forced prostitution and other criminal activities. They arrested Chinese criminals in Angola and took them back to China. It is the first time for the Chinese police to crack down on crimes infringing upon the legitimate rights and interests of Chinese in Africa by sending a working team to Africa, which opened a new chapter in the history of the police cooperation between China and Africa (Can and Jie, 2012).

Fifth, the officers of Chinese embassies and consulates have held a number of symposiums attended by Chinese citizens and delegates of Chinese enterprises in Africa. During these meetings, officials update them on the security situation, introduce consular protection and urge them to take responsibility in participating with local society and building a good foundation upon which the development of enterprise and the protection of Chinese citizens can be built. In October 2011, the Chinese Ambassador to Kenya held a meeting in the embassy regarding economic co-operation between China and Kenya and the ways in which Chinese enterprises in Kenya might enhance their public responsibility (Ministry of Foreign Affairs, 2011 d). In March 2013, the consul general attended a Chinese enterprise symposium in Lagos, Nigeria where he engaged with more than twenty principals of private enterprises (Ministry of Foreign Affairs, 2011 e). In April 2012, the Chinese Ambassador to Botswana held a meeting on consular protection (Ministry of For- 


\section{AFRICAN \\ EAST-ASIAN \\ AFFAIRS \\ THE CHINA MONITOR}

eign Affairs, 2012 d). Various community members attended including chairman of the Chinese Enterprises Association in Botswana, principal of Confucius Institute in Botswana, chairman in Chinese Chamber of Commerce, chairman of Peaceful Unification Promotion Agency, chairwoman of the Women's Institute, chairman of the Chinese Chamber of Commerce and other representatives

Sixth, the office in charge of Chinese embassies, consulates and various other correlative departments convene with local overseas Chinese associations and representatives of Chinese enterprises to hold meetings on introducing local policy and rules to Chinese citizens abroad. Subsequently Chinese citizens and firms follow the dictates formulated in these meetings so as to reduce risk when abroad. In November 2011, the Chinese Ambassador to Botswana and the Botswana Anti-Corruption and Economic Crime Investigation Bureau held a seminar to facilitate discussions between Botswana natives and overseas Chinese. Chinese-funded institutions and Botswana Industrial and Commercial Bureau released the Botswana Federation of Private Enterprises' Code of Conduct (Ministry of Foreign Affairs, 2011 f). In February 2012, the Chinese Ambassador to Zambia invited Zambia's employers' association to give a speech on Zambian Labour policy for Chinese enterprises and members of the Chinese Chamber of Commerce (Ministry of Foreign Affairs, 2012 e). In April 2011, The Chinese embassy to Togo organised an introductory meeting for Chinese citizens in Togo. A head of Togo's immigration department discussed issues of immigration_including Togo's visa and residence permit policy, working permit policy and the requirement to apply for long-term residence permits (Ministry of Foreign Affairs, 2012 f). In June 2011, the consulate general of Lagos organised several activities in which the consulate general introduced local laws, customs, industry rules and issues of risk prevention and control.

Seventh, Chinese Ambassadors to African states have inspected local Chinese enterprises and observed safety conditions at work. In March 2011, China's ambassador to Ethiopia visited Oro state capital city of Adama, location of a concentration Chinese enterprises, and held a seminar on consular protection work. (Ministry of Foreign 
Affairs, 2011 g). In November 2011, the Chinese Ambassador to Nigeria visited the agencies of ZTE Corporation and Huawei in Abuja and emphasised that the firms should focus on security, establish ethical security rules and formulate emergency plans (Ministry of Foreign Affairs, 2011 h).

Eighth, there has been the creation overseas Chinese consular protection cards (in the form of documentation of registered Chinese citizens and companies) and establishing a system of co-ordinated consular protection. In order to help overseas Chinese communicate their queries to the embassy and seek consular protection, the Chinese Ambassador to Botswana established overseas Chinese consular protection cards in Botswana so that overseas Chinese could access consular protection when needed (Ministry of Foreign Affairs, 2012 c). In addition, the Chinese ambassador to Botswana asked that overseas Chinese associations select members of the community to serve as consular protection coordinators and to update the Chinese embassy on the community's current situation. The consular section officers of the embassy hold consular protection coordinator meetings regularly. The Chinese ambassador to Sudan has built up a system in which all staff of firms which register are part of a network of communication (People's Daily, 2012 b ).

Ninth, Chinese embassies business departments keep touch with local business through irregular meetings and networks. The author's questionnaire showed that $58.9 \%$ of companies interviewed claimed that the Chinese embassy had held occasional meetings with them in the context of emergency notification; $32.3 \%$ of companies claimed that the Chinese embassy held regular meetings with them with regards to emergency situations. Various Chinese embassies abroad hold occasional security meetings attended by representatives of local business communities. The department, via websites (including the embassy website), "QQ" web chat forums and overseas Chinese websites publish security notices ${ }^{6}$.

Tenth, Chinese enterprises in Africa have a strong sense of risk prevention awareness, and invest much by way of security. In November 2011, diplomats from the Chinese embassy in Kenya were interviewed by the author. They claimed that in 


\section{AFRICAN \\ EAST-ASIAN \\ AFFAIRS \\ THE CHINA MONITOR}

the case of a serious security situation, Chinese enterprises hire local security, normally up to ten people, but in some cases there have been more than fifty. In other cases, hired armed police have been employed. In Kenya, there are two organizations, the China Economic and Trade Association of Kenya and The Federation of Overseas Chinese. The embassy officers go through these two organizations to disseminate information on security measures to Chinese enterprises and citizens in $\mathrm{Kenya}^{7}$. In May 2012, a representative of China Hydropower Construction Group in Ethiopia, told the author that the company took many measures to protect their staff. They had pre-arrival training and are taught to pay attention to construction-site safety. When the staff arrive Ethiopia, the representative agency employs an expert to give lectures on the cultural and religious differences between the inhabitants of north and south Ethiopia. During operations in dangerous areas, local police and security are hired; fences have been heightened, no night working is allowed and finance staff are accompanied by security guards when transiting cash. The commerce association in Ethiopia gives workers training, including lectures by lawyers about local laws, labour and tax policy. Chinese enterprises also share their experiences with each other. "QQ groups" between Chinese enterprises employees in Ethiopia communicate to each other about resources, HR and finance ${ }^{8}$. In response to the question "which measures do your company take in the protection of staff safety?", 78.9\% respondents stated that they hire local security companies; $70.3 \%$ chose building walls around working and living areas; $64.1 \%$ said that the company established detailed security measures, including drilling and regular checks; $20.3 \%$ used local army to help with security work. $7.8 \%$ and $7 \%$ said the company dug ditches around residential areas and hired Chinese security.

\section{Sufficient measures for consular protection}

The Chinese embassy has ordered big state-owned companies to have emergency plans. For example, the business section of the Chinese embassy in Ethiopia has requested state-owned companies and big private companies to report their emergency plans, with warnings issued to those who have not submitted plans. Plans included 
emergency evacuation routes and the appointment of responsible persons to supervise the task. The embassy visits each firm to observe demonstrations of the plan, including fire escape checks and lists of safety precautions.

Emergencies are categorized into several levels, employing different colours to indicate different emergency situations. The consular section of the embassy has also circulated various documents on emergency consular protection. The business section of the Chinese embassy in Ethiopia relies on the commerce association to send their notices to Chinese enterprises; and there are "QQ" groups between the department and the companies. If they encounter an emergency, the department will inform the principal of the association and two secretaries (separately in change contracting enterprise and investment enterprises), who will inform enterprise representatives.

Second, in terms of dealing with Chinese citizens' emergencies in Africa, the consular protection emergency mechanism draws on a "four in one" feature. The "four in one" feature refers to coordination between the central government, local Chinese communities abroad, enterprises abroad and local embassies (Xinhua 2012). The escape from Libya in 2011 demonstrated this feature clearly, where the four parties coordinated together and successfully finished the escape mission, which was praised by the media ${ }^{9}$. While the escape mission from Libya was led by the central government, the ammunition depot explosion accident in the Republic of Congo in March 2012 was an example of how emergency measures were led by local government. The Chinese Ambassador rushed to the disaster scene to coordinate the rescue work and help guide related companies in handling followup affairs. On the $5^{\text {th }}$ of March 2012, the vice foreign minister of China met with Congo (Brazzaville) embassy charge d'affaires. On $6^{\text {th }}$ of March 2012, the Chinese government quickly sent a team which included Beijing government officials, foreign ministry officials and other ministries to Congo (Brazzaville). The Beijing government sent a five member medical expert team. (Ministry of Foreign Affairs, $2012 \mathrm{~g})$. 


\section{AFRICAN \\ EAST-ASIAN \\ AFFAIRS \\ THE CHINA MONITOR}

Third, the foreign ministry, Chinese embassy to Africa and Chinese enterprises in Africa have attached great importance to the use of "Weibo","QQ" and other new communication tools to gather information and provide emergency help. In the Libya escape mission, China's Ministry of Foreign Affairs Consular Protection Centre not only used two hot lines and faxes to collect Chinese citizens helping information, but also used messages which Chinese citizens and institutes sent online via "Weibo". For example, some netizens reflected, via "Weibo" that there were more than eighty staff from a large Chinese telecommunications company in Tripoli which needed assistance. The Ministry of Foreign Affairs Consular Protection Centre asked local embassies to investigate two emergency situations, one regarding 800 Chinese citizens in Misrata, the other involving 48 Chinese citizens elsewhere in the country (Ministry of Foreign Affairs, 2011 i). In March 2012, after the ammunition depot explosion in the Republic of Congo, many netizens published information on "Weibo". The Chinese foreign ministry's Africa's official Weibo site, "Straight Africa", published many articles about this event, in which condolences were offered to Chinese victims, their families, the staff of Beijing Building Construction Company Consortium and the embassy of the Republic of Congo to China (Ministry of Foreign Affairs, $2012 \mathrm{~g}$ ).

This demonstrates that Chinese embassies in Africa positively cooperate with the Chinese enterprises in Africa, building diversified prevention mechanisms and employing effective emergency response mechanisms for the protection of Chinese citizens in Africa and Chinese enterprises in Africa.

\section{Some thinking of China's consular protection in Africa}

It is undeniable that Chinese consular protection in Africa has remained steadfast the Libya escape mission in early 2011 is one example. Nevertheless, there are still some questions worth considering.

Firstly, Chinese enterprises and Chinese citizens in Africa urgently need to increase their understanding of local laws and policy. As mentioned above in the question- 
naire, $61 \%$ of respondents thought that a major risk toward Chinese enterprises in Africa was due to a given company's a lack of understanding toward local laws and policy; $60 \%$ of respondents felt that their workers were ignorant of local laws and policy. Thus, more work needs to be done in terms of reinforcing research on Africa countries' laws and policy and the spreading of information

Secondly, to mitigate huge political risk purchasing investment insurance is very important. The questionnaire result showed that only less than one third $(27.3 \%)$ of Chinese enterprises in Africa purchased such insurance; $35.2 \%$ of respondents did not and the other $37.5 \%$ said they were undecided. This differs from firms in the developed world, in which insurance is far more prominent. Currently, China's insurance industry with regards to political risk is undeveloped.

Third, in terms of handling Chinese citizens' offences abroad, some Chinese embassies are prone to take the side of Chinese citizens, sometimes attempting to exempt Chinese citizens from punishment

The author discovered that some Chinese enterprises staff had been arrested for using fake invoices to avoid tax payments. However, when the local embassy received the information, they sent some staff to negotiate with local police, resulting in bail. Other Chinese citizens were caught with ivory but later released. The same situation occurred with South Koreans but they met with different consequences: they could not receive such help from their own embassy, and remained under arrest. While such measures offer a short-term solution to the problem, it encourages citizens to act unethically. Additionally it will hurt China's national image, damaging relations between China and Africa. Recently, there have been incidents of Chinese citizens fighting with the local police. In this sense, more overseas Chinese need to be alerted to the help they can receive from their embassies. The questionnaire data showed that $53.1 \%$ of respondents had heard about consular protection but were unclear with regards to specific information. 10.2\% of respondents said they did not even know what "consular protection" was. 


\section{AFRICAN \\ EAST-ASIAN \\ AFFAIRS \\ THE CHINA MONITOR}

Forth, in terms of building China's image within Africa, the behaviour of Chinese citizens, especially the staff in Chinese enterprises, was the most negative element. More and more Chinese workers arriving Africa have little awareness of local customs. Some workers do not respect local customs, look down on local people, and are engaged in conflict with locals. In May 2012, interviewees said that these phenomena are occurring more and more frequently. Moreover, lack of suitable problem solving methods threatens the security environment. For instance, on $16^{\text {th }}$ of June 2012 in Benin, the staff of a company discovered that a local person had stolen company diesel. What was meant to be a warning shot killed the thief. Following this, around 70 local people surrounded and attacked the company.

In conclusion, the risks which Chinese citizens and enterprises take in Africa are complex and lots of work still needs to be done in terms of China's consular protection. Recently, such protection has improved but many questions remain. In the practice of protection, personal interests, corporate interests and the interests of the state are bound up. In order to improve, there will be a greater need for the Chinese government, firms, media and citizens to work more closely together.

\section{Bibliography}

Can, X \& Jie, Y. 2012. 'Ministry of Public Security Meng Jianzhu detects violations of civil rights in Angola',[Online]. Available: http://www.cpd.com.cn/ n10216060/n10216144/c13238651/content.html. [ 2012, August 28]

CCTV News. 2007. China's African institutions should strengthen to protect themselves, [Online]. Available: http://news.cctv.com/ world/20070124/108131.shtml. [2007, January 24]

Ministry of Foreign Affairs. 2011 a. Chinese in Africa [Online]. Available: http:// www.fmprc.gov.cn/zflt/chn/zfgx/zfgxrwjl/t883665.htm. [2011, November 02] 
Ministry of Foreign Affairs. 2011 b. Ambassador to Ethiopia, Gu Xiaojie attends consular protection work symposium and outstanding Chinese enterprises, [Online]. Available: http://cs.mfa.gov.cn/lsxw/t806421.htm. [2011, March 15]

Ministry of Foreign Affairs. 2011 c. Chinese Embassy in Angola holds meeting with local police and Chinese Chamber of Commerce, [Online]. Available: http://cs.mfa.gov.cn/lsxw/t872004.htm. [2011, October 31]

Ministry of Foreign Affairs. 2011 d. Embassy in Kenya holds seminars funded by enterprises in Kenya, [Online]. Available: http://cs.mfa.gov.cn/lsxw/ t868096.htm. [2011, October 17]

Ministry of Foreign Affairs. 2011 e. Consul General in Lagos Liu Xianfa attends private enterprise seminars, [Online]. Available: http://cs.mfa.gov.cn/ lsxw/t916517.html. [2012, March 19]

Ministry of Foreign Affairs. $2011 \mathrm{f}$. The Chinese embassy to Botswana organizes seminars to prevent corruption and economic crime, [Online]. Available: http://cs.mfa.gov.cn/lsxw/t877912.htm [2011, November 16]

Ministry of Foreign Affairs. 2011 g. Chinese Ambassador to Ethiopia Gu Xiaojie visits to Oromia to hold Talks with Chinese business representatives and citizens, [Online]. Available: http://cs.mfa.gov.cn/lsxw/t806421.htm. [2011, March 15]

Ministry of Foreign Affairs. 2011 h. Ambassador to Nigeria, Deng Qing visits Chinese enterprises, [Online]. Available: http://cs.mfa.gov.cn/lsxw/ t875508.htm.[2011, November 9]

Ministry of Foreign Affairs. 2011 i. Ministry of foreign affairs attaches great importance to Chinese citizens' use of weibo for help. [Online].Available: http://cs.mfa.gov.cn/lsxw/t802626.htm. [2011, February 27]

Ministry of Foreign Affairs. 2012 a. The Ambassador to Mali Cao Zhongming 


\section{AFRICAN \\ EAST-ASIAN \\ AFFAIRS \\ THE CHINA MONITOR}

meets with Mali transitional government prime minister Diarra, [Online]. Available: 2012, http://cs.mfa.gov.cn/lsxw/t925568.htm. [2012 April, 25]

Ministry of Foreign Affairs. 2012 b. The Ambassador to Mozambique Huang Songfu meets Sino-Mozambican police defense mechanism" general coordinator of the Mozambican side, [Online]. Available: http://cs.mfa.gov.cn/lsxw/ t906360.htm. [2012, February 19]

Ministry of Foreign Affairs. 2012 c Charge d'affaires in Lesotho Lai Bo met with Assistant Secretary of State for Modise, [Online]. Available: http:// cs.mfa.gov.cn/lsxw/t918749.htm. [2012 March 29]

Ministry of Foreign Affairs. 2012 d. Botswana Embassy Consular Protection Symposium, [Online]. Available: http://cs.mfa.gov.cn/lsxw/t927375.htm. [2012, April 27]

Ministry of Foreign Affairs. 2012 e. The Chinese Ambassador to Zambia Yu Xiaozhou attends the seminar of Employers, [Online]. Available: http:// cs.mfa.gov.cn/lsxw/t909701.htm [2012, March 1]

Ministry of Foreign Affairs. 2012 f. The Chinese embassy to Togo holds meeting on introducing visa and residence permit policy, [Online]. Available: http:// cs.mfa.gov.cn/lsxw/t925547.htm. [2012, April 20]

Ministry of Foreign Affairs. 2012 g. Congo, bombing injured workers return to Beijing China, [Online]. Available: http://cs.mfa.gov.cn/lsxw/t913035.htm. [2012, March 12]

Ning, M \& Chang, Q. 2012. Beijing Youth Daily. Vol. A18, March 3

People's Daily. 2012 a. Deepen Pragmatic Co-operation, promote common development, September 7

People's Daily. 2012 b. How Chinese enterprises overseas should ensure their staffs' safety, February 2. 
Qichen Q. 2005. The Dictionary of Foreign Diplomacy, Beijing: World Affairs Press.

Sina News 2012. Experts claim our citizens are kidnaped abroad due to huge im-

pact of China, [Online]. Available: http://news.sina.com.cn/c/2012-0202/040323868772.shtml. [2012 February 8]

The department of consular affairs of the People's Republic of China. 2010. Chi$n a ' s$ consular protection and assistance guide. 2010. [Online]. Available: http://www.fmprc.gov.cn/chn/pds/fw/lsfw/lsbh/ P020091221621946131093.pdf, [2010, February 1]

Xinhua News. 2008. What can Enterprises and individuals do when facing problems overseas' speech on 'world knowledge. [Online]. Available: http:// news.xinhuanet.com/overseas/2008-08/31/content_9743308.htm. [2012, October 28]

Xinhua News. 2011. China accepts Libya's National Transitional Council, [Online]. Available: http://news.xinhuanet.com/world/2011-09/12/ c_122022307.htm. [2011, September 12]

Yi, L \& Chang, Q. 2012. Beijing Youth Daily, Vol. A19, March 23

\section{Endnotes}

1. The paper constitutes a sub-division of a larger research project entitled "A New Era of China-Africa Relations and Co-operation" (09JZD0039). The sub project is entitled "China's interests in Africa with reference to Consular Protection". This paper and is part of a Beijing Foreign Affairs and Communication Research Institute research initiative.

2. These states are Togo, Mauritania, Chad, Ghana, the Republic of Congo, Congo, Cameroon, the Republic of Cote d'Ivoire, Mali, Niger, the Central 


\section{AFRICAN \\ EAST-ASIAN AFFAIRS

African Republic, Benin, Ghana, Guinea, Nigeria, Senegal, Zambia and Namibia.

3. In the enterprises interviewed, almost a half (62 enterprises, accounting for 48per cent) are engaged in the construction contracting industry; 14per cent (18 enterprises) are in mining and energy industry; 7 per cent ( 9 firms) in foreign trade; 26per cent in other industries and 5per cent gave no response

4. The five companies are in four countries. These countries are Mauritania, Ghana, Senegal and Zambia.

5. Interview with a senior diplomat of the Chinese embassy in Tanzania on 24th of October 2012.

6. Interview with the Chinese embassy in Ethiopia business department officials in Addis Ababa on 24th of May 2012.

7. Interview with the Chinese embassy in Kenya, Nairobi, 18th of November 2011.

8. Interview on China Hydropower Construction Group International Engineering Co., Ltd. Representative Office in Ethiopia Liu Hailin on 22nd of May 2012.

9. On the detailed escape mission in Libya see: Liping, X. 2011. Evacuated from Libya: perspectives from China's consular protection construction mechanism. Journal of West Asia and Africa, vol 9: 105-119. 